\title{
Effect of Different Preservatives on Vase-Life of Cut Tuberose (Polianthes tuberosa L.) cv. Calcultta Single
}

\author{
Sweta Kumari ${ }^{1}$, B. Raghupathi ${ }^{1}$, Kumari Sarika ${ }^{2}$ and Prahlad Deb ${ }^{2}$ \\ ${ }^{1}$ Department of Floriculture and Landscape Architecture, Bidhan Chandra Krishi \\ Viswavidalaya, Mohanpur, Nadia, West Bengal-741252, India \\ ${ }^{2}$ Department of Crop Improvement, Horticulture and Agricultural Botany, Palli Siksha \\ Bhavna Visva- Bharati, Sriniketan, West Bengal-731235, India \\ *Corresponding author
}

\section{A B S T R A C T}

\begin{tabular}{|l|}
\hline Ke y w o r d s \\
Tuberose, Vase life, \\
Preservative, \\
Calcultta Double, \\
Sucrose
\end{tabular}

Tuberose (Polianthes tuberosa L.) is a perennial, bulbous flowering plant, belongs to family Amaryllidaceae. The study was conducted at postharvest research laboratory, Department of CIHAB, Palli Siksha Bhavana, Visva-Bharti, Sriniketan, Bolpur during the period of May 2014 to June 2014. Treatment details of experiment consists of $\mathrm{T}_{1}=$ Control, $\mathrm{T}_{2}=$ Sucrose $2.5 \%, \mathrm{~T}_{3}=$ Sucrose $5 \%, \mathrm{~T}_{4}=$ Citric acid 2.5\%, $\mathrm{T}_{5}=$ Citric acid 5\%, $\mathrm{T}_{6}=\mathrm{AgNO}_{3}$ $15 \mathrm{ppm}, \mathrm{T}_{7}=\mathrm{AgNO}_{3} 30 \mathrm{ppm}, \mathrm{T}_{8}=$ Sucrose $2.5 \%+$ Citric acid $2.5 \%, \mathrm{~T}_{9}=$ Sucrose $2.5 \%+$ Citric acid $5 \%, \mathrm{~T}_{10}=$ Sucrose $2.5 \%+\mathrm{AgNO}_{3} 15 \mathrm{ppm}$ and $\mathrm{T}_{11}=$ Sucrose $5 \%+\mathrm{AgNO}_{3}$ $25 \mathrm{ppm}$. Flowering spikes were kept in $200 \mathrm{ml}$ solution of $250 \mathrm{ml}$ conical flask and recorded different post-harvest observations. Conical flask mouths were covered with a sheet of polyethylene film. The experiment was laid out in Completely Randomized Design (CRD) with three replications. Experimental results relieved that different vase preservatives solutions were significantly affected the vase-life of tuberose flowers. The combination and concentration of Sucrose $2.5 \%$ and $\mathrm{AgNO}_{3} 15 \mathrm{ppm}$ were found to most suitable preservative solution for extending the vase life of tuberose cut flowers.

\section{Introduction}

Tuberose (Polianthes tuberosa L.) is a perennial, bulbous flowering plant, belongs to family Amaryllidaceae and is one of the most popular cut flower grown in India and as well as worldwide (Singh and Shanker, 2011). The white, sweet scented flowers are valued as cut flower, used in bouquets for making garlands, veins and as a source of essential oils for perfumery industries. Postharvest losses in many cut flowers are estimated to be as high as $40 \%$ in the absence of floral preservatives. Tuberose flowers are highly perishable in nature along with acropetalus movement of the florets along the spike, when flower spikes are harvested from the plant, there will be deterioration in the internal carbohydrates and loss in turgidity is accelerated, therefore need to be treated with suitable chemicals, to enhance their vase life and improve quality. The vase life of tuberose flowers in tap water is limited for only for few days. It has been reported that pulsing treatments prevents 
vascular infections and inhibit ethylene production and thereby result in prolong storage period and higher quality flowers with increased vase life (Vidhya Sankar and Bhattacharjee 2002).

Improvement of keeping quality and extend of vase life of cut flowers are important areas in floricultural research. Senescence of cut flowers is induced by several factors e.g. water stress, carbohydrate depletion, microorganism etc. Chemical preservatives are known to be antibacterial agents, water uptake enhancers along with other properties, are used for extending vase life of cut flowers. Whenever transpiration exceeds water uptake, resistance to water flow develops in the stems leading to water deficit. This resistance can be attributed to microbial occlusions, physiological vascular blockage or air embolism. Water uptake and water loss by harvested cut flowers in vases may fluctuate cylindrically with an overall declining trend. In India, commercial floriculture is a still upcoming trade and it offers a wide scope for experimentation, standardization and improvement of various techniques for enhancing vase life of cut flower. Therefore, the present study was carried out with an objective to evaluate the effect of different concentration of sucrose, citric acid and $\mathrm{AgNO}_{3}$ on vase life of tuberose cut flower.

\section{Materials and Methods}

The study was conducted at postharvest research laboratory, Department of CIHAB, Palli Siksha Bhavana, Visva-Bharti, Sriniketan, Bolpur during the period of May 2014 to June 2014. Tuberose flower spikes harvested in early morning 4AM from farmer field of Medinapur district, when one or two basal florets opened in flower spikes. Harvested flower spikes transported from Medinapur to Bolpur within 6 hours of harvesting time and flower spikes covered with plastic film during transportation to minimize the moisture loss. Flower spikes again in laboratory again were re-cut by 1.5 $2.5 \mathrm{~cm}$. The $50 \mathrm{~cm}$ length of each flower spike was maintained uniformly. The experiment was laid out in Completely Randomized Design (CRD) with three replications.

The vase solution is prepared at the beginning of experiment. Treatment details of holding solutions used in experiment consists of $\mathrm{T}_{1}=$ Control, $\mathrm{T}_{2}=$ Sucrose $2.5 \%, \mathrm{~T}_{3}=$ Sucrose $5 \%$, $\mathrm{T}_{4}=$ Citric acid $2.5 \%, \mathrm{~T}_{5}=$ Citric acid $5 \%, \mathrm{~T}_{6}=$ $\mathrm{AgNO}_{3} 15 \mathrm{ppm}, \mathrm{T}_{7}=\mathrm{AgNO}_{3} 30 \mathrm{ppm}, \mathrm{T}_{8}=$ Sucrose $2.5 \%+$ Citric acid $2.5 \%, \mathrm{~T}_{9}=$ Sucrose $2.5 \%+$ Citric acid $5 \%, \mathrm{~T}_{10}=$ Sucrose $2.5 \%+$ $\mathrm{AgNO}_{3} 15 \mathrm{ppm}$ and $\mathrm{T}_{11}=$ Sucrose $5 \%+$ $\mathrm{AgNO}_{3}$ 25ppm. The observations recorded on different postharvest parameters such as, gain or loss in fresh weight, total vase solution uptake, vase life in days, flower diameter, flower length, No. of florets opens and No. of flower drops. Flowering spikes were kept in $200 \mathrm{ml}$ solution of $250 \mathrm{ml}$ conical flask. Conical flask mouths were covered with a sheet of polyethylene film, to minimize evaporation and to reduce further contamination.

\section{Results and Discussion}

The amount of vase solution absorbed and loss or gain of flower weight in different vase preservatives

From the Table 1 it is clear that weight of all treatments were increased from $1^{\text {st }}$ to $5^{\text {th }}$ day and decreased from $7^{\text {th }}$ day. Among the treatments maximum weight gain and water uptake was observed by $\mathrm{T}_{10}$ (Sucrose $2.5 \%+$ $\mathrm{AgNO}_{3} 15 \mathrm{ppm}$ ) followed by $\mathrm{T}_{11}$ (Sucrose $5 \%$ $\left.+\mathrm{AgNO}_{3} 25 \mathrm{ppm}\right)$. The minimum weight gain and water uptake was observed in $\mathrm{T}_{1}$ (Control) followed by $\mathrm{T}_{2}$ (Sucrose $2.5 \%$ ). Similar results were reported by Hutchinson et al., (2003) on effect of accel, sucrose, and silver thiosulphate 
on water relations, post-harvest physiology of cut tuberose flowers and Talukdar et al., (2011) on effect of pulsing and different holding solutions on flower quality and vase life of tuberose (Polianthes tuberose L.) cv. Calcutta Double.

\section{Flower diameter $(\mathbf{c m})$}

The floret diameter of tuberose spikes showed the significant difference for different vase solution from fourth day onwards (Table 2). After harvesting initially flower diameter increases for first 2 days after that it decreases from 3 day onwards in all the treatments. Among the treatments, on $2^{\text {nd }}$ day the maximum flower diameter increase was observed in $\mathrm{T}_{10}$ (Sucrose $2.5 \%+\mathrm{AgNO}_{3}$ $15 \mathrm{ppm})(4.46 \mathrm{~cm})$ followed by $\mathrm{T}_{7}\left(\mathrm{AgNO}_{3}\right.$ $30 \mathrm{ppm}$ ) (4.44), whereas the minimum flower diameter was observed on $\mathrm{T}_{1}$ (Control) (4.04) followed by $\mathrm{T}_{2}$ (Sucrose $\left.2.5 \%\right)(4.09)$, on $4^{\text {th }}$ day also same treatments recorded maximum and minimum flower diameter.

The similar results were observed by Kumar et al., in (2003) on postharvest quality of tuberose spikes as affected by colouring agents and storage and Talukdar et al., (2011) on effect of pulsing and different holding solutions on flower quality and vase life of tuberose (Polianthes tuberose L.) cv. Calcutta Double.

\section{Flower length $(\mathrm{cm})$}

The flower length of tuberose spikes showed the significant difference for different vase solution from fourth day onwards. Flower length increases first 2 days after that it decreases (Table 3). On $4^{\text {th }}$ day maximum floret length increase was observed in $\mathrm{T}_{11}$ (Sucrose 5\% $+\mathrm{AgNO}_{3}$ 25ppm) (3.84) fallowed by $\mathrm{T}_{10}$ (Sucrose $2.5 \%+\mathrm{AgNO}_{3}$ $15 \mathrm{ppm}$ ) (3.82), whereas minimum floret length was observed in $\mathrm{T}_{1}$ (Control) (3.20) fallowed by $\mathrm{T}_{2}$ (Sucrose 2.5\%) (3.28) and $\mathrm{T}_{5}$ (Citric acid 5\%) (3.28) are found similar. Findings were in similar with Talukdar et al., (2011) on effect of pulsing and different holding solutions on flower quality and vase life of tuberose (Polianthes tuberose L.) cv. Calcutta Double.

\section{Number of flower open}

From the Table 4, it is clear that, number of flower open per day per spike showed significant difference for different vase solution from $1^{\text {st }}$ to $4^{\text {th }}$ day. On $4^{\text {th }}$ day of observation, maximum number of florets was opened in $\mathrm{T}_{10}\left(\right.$ Sucrose $\left.2.5 \%+\mathrm{AgNO}_{3} 15 \mathrm{ppm}\right)$ (4.33) and minimum number of florets opening occurred in $\mathrm{T}_{1}$ (Control) (2.33) followed by $\mathrm{T}_{2}$ (2.66).

The average number of florets (3.33) opening occurred in $\mathrm{T}_{4}$ (Citric acid), $\mathrm{T}_{6}\left(\mathrm{AgNO}_{3}\right.$ $15 \mathrm{ppm}), \mathrm{T}_{7}\left(\mathrm{AgNO}_{3} 30 \mathrm{ppm}\right), \mathrm{T}_{8}$ (Sucrose $2.5 \%+$ Citric acid 2.5\%), $\mathrm{T}_{11}$ (Sucrose 5\%+ $\left.\mathrm{AgNO}_{3} 25 \mathrm{ppm}\right)$. Similar results were reported by Adarsh et al., (2010) on Vase life studies in tuberose (Polianthes tuberosa) cv. Shringar as affected by post-harvest handling treatments.

\section{No. of flower drop}

Table 5 shows the effect of different vase preservatives on the number flower drop in tuberose. Significant no. of flower drop observed from $5^{\text {th }}$ day onwards.

On the ninth day of observation, maximum no. of flower drop occurred in $\mathrm{T}_{1}$ (Control) (6.67), followed by $\mathrm{T}_{2}$ (Sucrose 2.5\%) (5.57) and minimum no. flower drop occurred in $\mathrm{T}_{10}$ (Sucrose 2.5\% + $\mathrm{AgNO}_{3} 15 \mathrm{ppm}$ ) (2.67) followed by $\mathrm{T}_{11}$ (Sucrose $5 \%+\mathrm{AgNO}_{3}$ 25ppm) (3.67). Jowkar, et al., (2005) reported similar results on effect of different vase preservative solutions on vase life of cut flowers. 
Table.1 Effect of different vase preservatives on gain or loss in fresh weight and total vase solution uptake of tuberose

\begin{tabular}{|c|c|c|c|c|c|c|}
\hline \multirow[t]{2}{*}{ Treatment } & \multicolumn{5}{|c|}{ Gain or loss in fresh weight (g) } & \multirow{2}{*}{$\begin{array}{c}\text { Total vase solution } \\
\text { uptake (g) }\end{array}$} \\
\hline & $1^{\text {st }}$ day & $3^{\text {rd day }}$ & $5^{\text {th }}$ day & $7^{\text {th }}$ day & $9^{\text {th }}$ day & \\
\hline$\overline{T_{1}}$ & 58.00 & 63.83 & 64.63 & 61.00 & 53.33 & 47.00 \\
\hline$T_{2}$ & 58.00 & 64.33 & 66.00 & 63.00 & 57.00 & 51.67 \\
\hline $\mathbf{T}_{\mathbf{3}}$ & 57.33 & 68.00 & 71.00 & 63.67 & 62.00 & 53.00 \\
\hline $\mathbf{T}_{4}$ & 56.00 & 66.80 & 68.80 & 65.00 & 61.00 & 54.33 \\
\hline $\mathbf{T}_{5}$ & 56.33 & 67.00 & 68.77 & 66.00 & 63.00 & 53.66 \\
\hline $\mathrm{T}_{6}$ & 57.67 & 67.07 & 69.5 & 65.00 & 62.00 & 54.67 \\
\hline$\overline{\mathbf{T}_{7}}$ & 57.67 & 71.78 & 74.97 & 66.00 & 65.00 & 56.66 \\
\hline$T_{8}$ & 58.33 & 70.67 & 74.17 & 69.17 & 66.00 & 57.00 \\
\hline $\mathrm{T}_{9}$ & 56.67 & 71.55 & 75.25 & 71.00 & 67.00 & 55.67 \\
\hline$T_{10}$ & 56.56 & 73.20 & 77.2 & 72.47 & 70.47 & 58.00 \\
\hline $\mathbf{T}_{11}$ & 59.67 & 72.03 & 75 & 71.33 & 68.00 & 57.33 \\
\hline CD & 0.26 & 2.35 & 2.312 & 0.58 & 0.72 & 2.01 \\
\hline SE (m) & 0.78 & 0.80 & 0.79 & 1.70 & 2.11 & 0.68 \\
\hline
\end{tabular}

$\left(\mathrm{T}_{1}=\right.$ Control, $\mathrm{T}_{2}=$ Sucrose 2.5\%, $\mathrm{T}_{3}=$ Sucrose 5\%, $\mathrm{T}_{4}=$ Citric acid 2.5\%, $\mathrm{T}_{5}=$ Citric acid 5\%, $\mathrm{T}_{6}=\mathrm{AgNO}_{3} 15 \mathrm{ppm}$, $\mathrm{T}_{7}=\mathrm{AgNO}_{3} 30 \mathrm{ppm}, \mathrm{T}_{8}=$ Sucrose $2.5 \%+$ Citric acid 2.5\%, $\mathrm{T}_{9}=$ Sucrose $2.5 \%+$ Citric acid $5 \%, \mathrm{~T}_{10}=$ Sucrose $2.5 \%+$ $\mathrm{AgNO}_{3} 15 \mathrm{ppm}$ and $\mathrm{T}_{11}=$ Sucrose $5 \%+\mathrm{AgNO}_{3} 25 \mathrm{ppm}$ )

Table.2 Effect of different vase preservatives on flower diameter of tuberose

\begin{tabular}{|c|c|c|c|c|c|}
\hline Treatments & Zero day & $\mathbf{1}^{\text {st }} \mathbf{d a y}$ & $\mathbf{2}^{\text {nd }}$ day & $\mathbf{3}^{\text {rd }}$ day & $\mathbf{4}^{\text {th }}$ day \\
\hline $\mathbf{T}_{\mathbf{1}}$ & 3.04 & 3.30 & 4.04 & 4.01 & 2.25 \\
\hline $\mathbf{T}_{\mathbf{2}}$ & 3.16 & 3.38 & 4.09 & 4.02 & 2.26 \\
\hline $\mathbf{T}_{\mathbf{3}}$ & 3.17 & 3.52 & 4.18 & 4.09 & 2.35 \\
\hline $\mathbf{T}_{\mathbf{4}}$ & 3.16 & 3.41 & 4.18 & 4.10 & 2.28 \\
\hline $\mathbf{T}_{\mathbf{5}}$ & 3.14 & 3.38 & 4.22 & 4.12 & 2.26 \\
\hline $\mathbf{T}_{\mathbf{6}}$ & 3.18 & 3.46 & 4.23 & 4.15 & 2.28 \\
\hline $\mathbf{T}_{\mathbf{7}}$ & 3.24 & 3.77 & 4.44 & 4.30 & 2.46 \\
\hline $\mathrm{T}_{\mathbf{8}}$ & 3.29 & 3.68 & 4.32 & 4.21 & 2.37 \\
\hline $\mathbf{T}_{\mathbf{9}}$ & 3.44 & 3.73 & 4.32 & 4.25 & 2.40 \\
\hline $\mathbf{T}_{\mathbf{1 0}}$ & 3.60 & 3.91 & 4.46 & 4.33 & 2.50 \\
\hline $\mathbf{T}_{\mathbf{1 1}}$ & 3.40 & 3.74 & 4.38 & 4.24 & 2.46 \\
\hline $\mathrm{C} . \mathbf{D}$. & $\mathbf{0 . 0 7}$ & $\mathbf{0 . 0 5}$ & $\mathbf{0 . 0 7}$ & $\mathbf{0 . 0 5}$ & $\mathbf{0 . 0 6}$ \\
\hline $\mathrm{SE}(\mathbf{m})$ & $\mathbf{0 . 0 3}$ & $\mathbf{0 . 0 2}$ & $\mathbf{0 . 0 2}$ & $\mathbf{0 . 0 2}$ & $\mathbf{0 . 0 2}$ \\
\hline
\end{tabular}

$\left(\mathrm{T}_{1}=\right.$ Control, $\mathrm{T}_{2}=$ Sucrose 2.5\%, $\mathrm{T}_{3}=$ Sucrose 5\%, $\mathrm{T}_{4}=$ Citric acid 2.5\%, $\mathrm{T}_{5}=$ Citric acid 5\%, $\mathrm{T}_{6}=\mathrm{AgNO}_{3} 15 \mathrm{ppm}$, $\mathrm{T}_{7}=\mathrm{AgNO}_{3} 30 \mathrm{ppm}, \mathrm{T}_{8}=$ Sucrose $2.5 \%+$ Citric acid 2.5\%, $\mathrm{T}_{9}=$ Sucrose $2.5 \%+$ Citric acid $5 \%, \mathrm{~T}_{10}=$ Sucrose $2.5 \%+$ $\mathrm{AgNO}_{3} 15 \mathrm{ppm}$ and $\mathrm{T}_{11}=$ Sucrose $\left.5 \%+\mathrm{AgNO}_{3} 25 \mathrm{ppm}\right)$ 
Table.3 Effect of different vase preservatives on flower length of tuberose

\begin{tabular}{|c|c|c|c|c|c|}
\hline Treatment & Zero day & $\mathbf{1}^{\text {st }}$ day & $\mathbf{2}^{\text {nd }}$ day & $\mathbf{3}^{\text {rd }}$ day & $\mathbf{4}^{\text {th }}$ day \\
\hline $\mathbf{T}_{\mathbf{1}}$ & 3.52 & 4.51 & 4.72 & 3.62 & 3.20 \\
\hline $\mathbf{T}_{\mathbf{2}}$ & 3.57 & 4.62 & 4.81 & 3.68 & 3.28 \\
\hline $\mathbf{T}_{\mathbf{3}}$ & 3.73 & 4.71 & 4.95 & 3.83 & 3.49 \\
\hline $\mathbf{T}_{\mathbf{4}}$ & 3.62 & 4.61 & 4.81 & 3.73 & 3.36 \\
\hline $\mathbf{T}_{\mathbf{5}}$ & 3.57 & 4.42 & 4.62 & 3.72 & 3.28 \\
\hline $\mathbf{T}_{\mathbf{6}}$ & 3.67 & 4.46 & 4.64 & 3.78 & 3.32 \\
\hline $\mathbf{T}_{\mathbf{7}}$ & 3.92 & 5.01 & 5.13 & 3.90 & 3.72 \\
\hline $\mathbf{T}_{\mathbf{8}}$ & 3.81 & 4.92 & 5.04 & 3.81 & 3.60 \\
\hline $\mathbf{T}_{\mathbf{9}}$ & 3.83 & 4.94 & 5.17 & 3.86 & 3.66 \\
\hline $\mathbf{T}_{\mathbf{1 0}}$ & 4.05 & 5.17 & 5.27 & 4.04 & 3.82 \\
\hline $\mathbf{T}_{\mathbf{1 1}}$ & 3.87 & 4.94 & 5.18 & 3.92 & 3.84 \\
\hline $\mathrm{C.D}_{\mathbf{D}}$ & $\mathbf{0 . 0 4}$ & $\mathbf{0 . 0 3}$ & $\mathbf{0 . 0 4}$ & $\mathbf{0 . 0 3}$ & $\mathbf{0 . 0 5}$ \\
\hline SE(m) & $\mathbf{0 . 0 2}$ & $\mathbf{0 . 0 1}$ & $\mathbf{0 . 0 1}$ & $\mathbf{0 . 0 1}$ & $\mathbf{0 . 0 2}$ \\
\hline
\end{tabular}

$\left(\mathrm{T}_{1}=\right.$ Control, $\mathrm{T}_{2}=$ Sucrose $2.5 \%, \mathrm{~T}_{3}=$ Sucrose $5 \%, \mathrm{~T}_{4}=$ Citric acid $2.5 \%, \mathrm{~T}_{5}=$ Citric acid $5 \%, \mathrm{~T}_{6}=\mathrm{AgNO}_{3} 15 \mathrm{ppm}$, $\mathrm{T}_{7}=\mathrm{AgNO}_{3} 30 \mathrm{ppm}, \mathrm{T}_{8}=$ Sucrose $2.5 \%+$ Citric acid 2.5\%, $\mathrm{T}_{9}=$ Sucrose $2.5 \%+$ Citric acid $5 \%, \mathrm{~T}_{10}=$ Sucrose $2.5 \%+$ $\mathrm{AgNO}_{3} 15 \mathrm{ppm}$ and $\mathrm{T}_{11}=$ Sucrose $\left.5 \%+\mathrm{AgNO}_{3} 25 \mathrm{ppm}\right)$

Table.4 Effect of different vase preservatives on number of flower open in tuberose

\begin{tabular}{|c|c|c|c|c|c|}
\hline Treatment & Zero day & $\mathbf{1}^{\text {st }}$ day & $\mathbf{2}^{\text {nd }}$ day & $\mathbf{3}^{\text {rd }}$ day & $\mathbf{4}^{\text {th }}$ day \\
\hline $\mathbf{T}_{\mathbf{1}}$ & 1.67 & 4.00 & 5.67 & 4.33 & 2.33 \\
\hline $\mathbf{T}_{\mathbf{2}}$ & 2.33 & 4.33 & 6.00 & 4.67 & 2.66 \\
\hline $\mathbf{T}_{\mathbf{3}}$ & 2.67 & 4.67 & 6.67 & 5.33 & 3.00 \\
\hline $\mathbf{T}_{\mathbf{4}}$ & 2.33 & 5.00 & 6.33 & 5.33 & 3.33 \\
\hline $\mathbf{T}_{\mathbf{5}}$ & 2.67 & 5.33 & 5.67 & 5.67 & 3.67 \\
\hline $\mathbf{T}_{\mathbf{6}}$ & 2.67 & 5.67 & 6.00 & 6.00 & 3.33 \\
\hline $\mathbf{T}_{\mathbf{7}}$ & 2.33 & 6.00 & 6.67 & 5.67 & 3.33 \\
\hline $\mathrm{T}_{\mathbf{8}}$ & 2.67 & 5.67 & 6.33 & 5.33 & 3.33 \\
\hline $\mathbf{T}_{\mathbf{9}}$ & 2.67 & 5.33 & 7.00 & 5.67 & 3.00 \\
\hline $\mathbf{T}_{\mathbf{1 0}}$ & 2.67 & 6.33 & 7.33 & 6.67 & 4.33 \\
\hline $\mathbf{T}_{\mathbf{1 1}}$ & 1.67 & 5.67 & 6.33 & 5.67 & 3.33 \\
\hline C.D. & $\mathbf{N} / \mathbf{A}$ & $\mathbf{0 . 9 8}$ & $\mathbf{0 . 9 8}$ & $\mathbf{1 . 0 7}$ & $\mathbf{N} / \mathbf{A}$ \\
\hline $\mathrm{SE}(\mathbf{m})$ & $\mathbf{0 . 4 5}$ & $\mathbf{0 . 3 3}$ & $\mathbf{0 . 3 3}$ & $\mathbf{0 . 3 6}$ & $\mathbf{0 . 4 3}$ \\
\hline
\end{tabular}

( $\mathrm{T}_{1}=$ Control, $\mathrm{T}_{2}=$ Sucrose $2.5 \%, \mathrm{~T}_{3}=$ Sucrose $5 \%, \mathrm{~T}_{4}=$ Citric acid 2.5\%, $\mathrm{T}_{5}=$ Citric acid 5\%, $\mathrm{T}_{6}=\mathrm{AgNO}_{3} 15 \mathrm{ppm}$, $\mathrm{T}_{7}=\mathrm{AgNO}_{3} 30 \mathrm{ppm}, \mathrm{T}_{8}=$ Sucrose $2.5 \%+$ Citric acid 2.5\%, $\mathrm{T}_{9}=$ Sucrose $2.5 \%+$ Citric acid $5 \%, \mathrm{~T}_{10}=$ Sucrose $2.5 \%+$ $\mathrm{AgNO}_{3} 15 \mathrm{ppm}$ and $\mathrm{T}_{11}=$ Sucrose $\left.5 \%+\mathrm{AgNO}_{3} 25 \mathrm{ppm}\right)$ 
Table.5 Effect of different vase preservatives on of no. flower drop flower of tuberose

\begin{tabular}{|c|c|c|c|c|c|}
\hline Treatment & $5^{\text {th }}$ day & $6^{\text {th }}$ day & $7^{\text {th }}$ day & $8^{\text {th }}$ day & $9^{\text {th }}$ \\
\hline$T_{1}$ & 3.33 & 4.00 & 5.00 & 5.67 & 6.67 \\
\hline $\mathrm{T}_{2}$ & 3.00 & 3.67 & 4.33 & 5.33 & 5.67 \\
\hline$T_{3}$ & 2.00 & 3.00 & 4.00 & 5.00 & 5.33 \\
\hline$T_{4}$ & 1.67 & 2.33 & 2.67 & 5.00 & 5.33 \\
\hline $\mathrm{T}_{5}$ & 2.00 & 3.00 & 4.00 & 5.00 & 5.00 \\
\hline$T_{6}$ & 2.00 & 2.67 & 4.67 & 5.33 & 5.33 \\
\hline $\mathrm{T}_{7}$ & 1.00 & 2.00 & 3.67 & 4.00 & 4.33 \\
\hline $\mathrm{T}_{8}$ & 0.67 & 1.33 & 2.67 & 3.67 & 4.33 \\
\hline $\mathrm{T}_{9}$ & 1.33 & 2.00 & 2.33 & 3.33 & 4.00 \\
\hline$T_{10}$ & 0.67 & 1.33 & 1.67 & 2.67 & 2.67 \\
\hline$T_{11}$ & 1.00 & 2.00 & 3.00 & 3.33 & 3.67 \\
\hline C.D. & 1.68 & 1.51 & 1.65 & 1.19 & 1.15 \\
\hline $\mathbf{S E}(\mathbf{m})$ & 0.57 & 0.51 & 0.56 & 0.40 & 0.39 \\
\hline
\end{tabular}

$\left(\mathrm{T}_{1}=\right.$ Control, $\mathrm{T}_{2}=$ Sucrose $2.5 \%, \mathrm{~T}_{3}=$ Sucrose $5 \%, \mathrm{~T}_{4}=$ Citric acid $2.5 \%, \mathrm{~T}_{5}=$ Citric acid $5 \%, \mathrm{~T}_{6}=\mathrm{AgNO}_{3} 15 \mathrm{ppm}$, $\mathrm{T}_{7}=\mathrm{AgNO}_{3} 30 \mathrm{ppm}, \mathrm{T}_{8}=$ Sucrose $2.5 \%+$ Citric acid 2.5\%, $\mathrm{T}_{9}=$ Sucrose $2.5 \%+$ Citric acid $5 \%, \mathrm{~T}_{10}=$ Sucrose $2.5 \%+$ $\mathrm{AgNO}_{3} 15 \mathrm{ppm}$ and $\mathrm{T}_{11}=$ Sucrose $\left.5 \%+\mathrm{AgNO}_{3} 25 \mathrm{ppm}\right)$

Fig.1 Tuberose spike in different vase solution

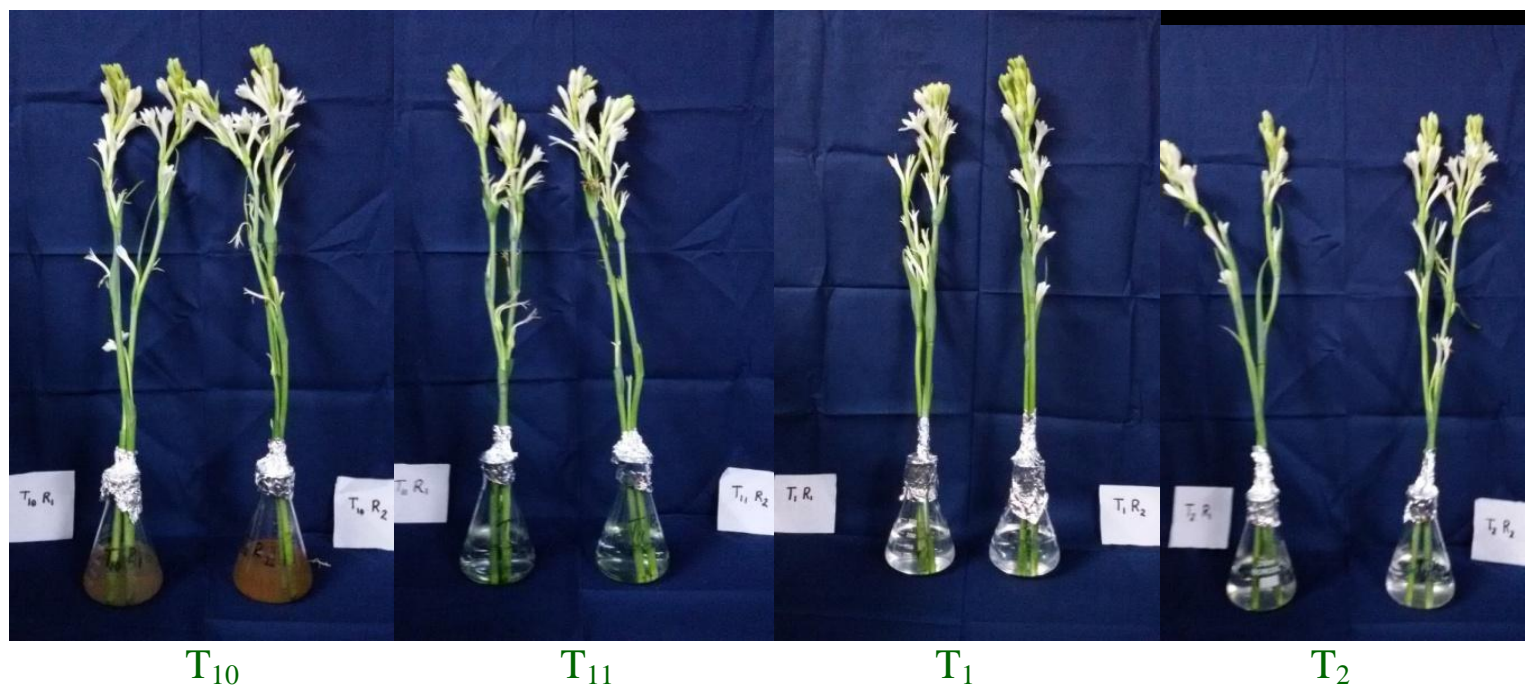

\section{Vase life of flowers (Days)}

Vase life of tuberose cut spikes showed significant difference for different vase preservatives treatments. From all the above tables it can be observed maximum vase life was recorded in $\mathrm{T}_{10}$ (Sucrose $2.5 \%+\mathrm{AgNO} 3$ $15 \mathrm{ppm}$ ) (2.67) followed by $\mathrm{T}_{11}$ (Sucrose $5 \%+$ $\mathrm{AgNO}_{3}$ 25ppm) (3.67), whereas minimum vase life was found in $\mathrm{T}_{1}$ (Control), followed by $\mathrm{T}_{2}$ (Sucrose $2.5 \%$ ). Findings were in similar with Mahraoo et al., (2009) on effect of different concentrations of four preservatives solutions on tuberose and Talukdar et al., (2011) on effect of pulsing and different holding solutions on flower quality and vase life of tuberose (Polianthes tuberose L.) cv. Calcutta Double. The maximum uptake of water by the flowers in the treatments might be due to influence of pulsing with silver nitrate which helped in increased uptake of water and germicidal properties of $\mathrm{AgNO}_{3}$ in 
addition to inhibition of ethylene biosynthesis which resulted in gain in fresh weight. This might be due to the presence of sucrose in the solution that had acted as a food source or respiratory substrate and delayed the degradation of proteins and improved water balance of cut flowers. Steinitz (1982) opined that addition of sucrose to the solution increased the mechanical rigidity of the stem inducing cell wall thickening and lignifications of vascular tissues. Sucrose antagonized the effect of ABA, which promoted senescence. The reason being that water uptake may be the important factor in improving the length of vase life of cut flower (Halevy and Mayank, 1979). As the leaves on flower transpire, water is dawn up through the xylem. If the process is impeded by a vascular blockage and accelerated by increased stomatal opening, then transpiration will exceed, uptake and water deficiency will occur. So solutes like sucrose $2.5 \%+\mathrm{AgNO}_{3}$ $15 \mathrm{ppm}$ added to vase solutions, can decrease transpiration or increase water uptake (Van Drawn, 1998). So flower remains fresh for more days.

From the above results, it can be concluded that different vase preservatives solutions significantly affected the vase-life of tuberose flowers. The combination of Sucrose $2.5 \%$ and $\mathrm{AgNO}_{3} 15 \mathrm{ppm}$ concentration found to most suitable preservative for extending vase life of tuberose cut flowers.

\section{References}

Adarsh, K., Sanjeev, K., and Chandra, S., 2010. Vase Life Studies in Tuberose (Polianthes tuberosa) Cv. Shringar as Affected by Post Harvest Handling Treatments. The J. Asian Hort. 5 (1): 7 10.
Halevy, A. H. and Mayank, 1976. Treatments to Improve Water Balance of Cut Flowers. Acta Hort. 64:223-226.

Hutchinson, M. J., Chebet, D. K., and Emongor, V. E., 2003. Effect of Accel, Sucrose and Silver Thiosulphate on the Water Relations and Post-Harvest Physiology of Cut Tuberose Flowers. J. African crop science. 11 (4): 279-287.

Jowkar, M. M. and Salehi, H., 2005. Effects of Different Preservatives Solutions Solutions on the Vaselife of Cut Flowers, Act Hort. 669.

Kumar, V., Battacharjee, S. K., Rajive Kumar, R., Misra, L. and Krishnan. P. S., 2003. Post-Harvest and Quality of Tuberose Spikes As Affected By Colouring Agents and Storage. J. of Ornamental Hort. 6 (2):119

Mahroo, S. M. and Ashari, E. M., 2009. Effect of Different Concentrations of Four Preservatives Solutions on Tuberose (Polianthes tuberose L.) Cut Flower Vase Life. J. Flori and ornamental Biotec. 3 (1): 59-61.

Singh, A. K. and K. Shankar, 2011. Effect of Plant Growth Regulators on Vegetative Growth and Flowering Behaviour of Tuberose (Polianthes tuberosa L.) cv. Double. Plant Arch. 11: 123-125.

Steinitz, B., 1982. Role of Sucrose in Stabilization of Cut Gerbera Flower Stalk. Gartenbouwissenschaft 47:77-81.

Talukdar, M. C. and Barooah, L., 2011. Effect of Pulsing and Different Holding Solutions on Flower Quality and Vase life of Tuberose (Polianthes tuberose L.) cv. Calcutta Double, J. Ind hill farming. 24 (1): 31-33.

Vidhya, S. and Bhattacharjee, S. K., 2002. Floriculture Research Trend in India. Ind Soc. Ornamental Hort. New Delhi, pp.83-86.

\section{How to cite this article:}

Sweta Kumari, B. Raghupathi, Kumari Sarika and Prahlad Deb. 2018. Effect of Different Preservatives on Vase-Life of Cut Tuberose (Polianthes tuberosa L.) cv. Calcultta Single. Int.J.Curr.Microbiol.App.Sci. 7(01): 1651-1657. doi: https://doi.org/10.20546/ijcmas.2018.701.200 